\title{
Analisis Kompetensi Profesional Guru Mata Pelajaran Pengantar Administrasi Di Jurusan Administrasi Perkantoran SMK YPLP PGRI 1 Makassar
}

\author{
Analysis of Professional Competencies in Teacher Introduction to \\ Administration in the Office Administration Department \\ SMK YPLP PGRI 1 Makassar
}

\author{
Fadly Fadlun Renhoran ${ }^{1}$, Sirajuddin Saleh ${ }^{2}$, Muhammad Darwis ${ }^{3}$. \\ 1,2,3Universitas Negeri Makassar
}

\begin{abstract}
ABSTRAK
Penelitian ini bertujuan untuk mengetahui kompetensi profesional guru Pelajaran Pengantar Administrasi Jurusan Administrasi Perkantoran SMK YPLP PGRI 1 Makassar. Penelitian ini menggunakan jenis penelitian kualitatif dengan pendekatan deskriptif kualitatif. Informan dalam penelitian ini sebanyak 5 (lima) orang. Pengumpulan data dilakukan melalui teknik wawancara, observasi, dan dokumentasi. Data yang telah dikumpulkan diolah dengan menggunakan teknik analisis yaitu reduksi data, penyajian data dan kesimpulan atau verifikasi. Hasil penelitian menunjukkan bahwa kompetensi profesional guru mata pelajaran pengantar administrasi jurusan Administrasi Perkantoran SMK YPLP PGRI 1 Makassar pada umunya sudah terlaksana dengan baik. Hal ini dinilai dari kelima indikator kompetensi profesional guru seperti, menguasai landasan pendidikan, yakni mampu memahami tujuan pendidikan untuk mencapai tujuan pendidikan nasional, mengusai bahan pengajaran, dengan menguasai bahan pengajaran kurikulum dan penyusunan program pengajaran, juga telah optimal dalam menetapkan tujuan pembelajaran, kemudian melaksanakan program pengajaran, dimana telah menciptakan iklim belajar mengajar yang tepat, dan menilai hasil dan proses belajar mengajar yang telah dilaksanakan dengan baik. Jadi kompetensi profesional guru mata pelajaran pengantar administrasi jurusan adminsitrasi perkantoran SMK YPLP PGRI 1 Makassar telah terimplementasi dengan baik.
\end{abstract}

Kata Kunci: Kompetensi, profesional, administrasi perkantoran

\section{ABSTRACT}

This study aims to study the professional competence of the introductory teaching teacher of Administrative Office Administration Department of YPLP PGRI 1 in Makassar. This study uses a type of qualitative research with qualitative descriptive research. Informants in this study were 5 (five) people. Data collection is done through interview, observation, and documentation techniques. The collected data is processed using analytical techniques, namely data reduction, data presentation and conclusions or verification. The results of the study show that the professional competence of the introductory teacher of administration in the Department of Office Administration at YPLP PGRI 1 Makassar in general has been well implemented. This discusses the agreement of professional teacher competency indicators, moves the field of education, outlines the goals of education to achieve national education goals, seeks consideration, by collecting materials related to the curriculum and developing the program developed, has also supported optimally in directing goals learning, then holding an agreed program, which has succeeded in developing appropriate teaching and learning, and the assessment of the results and teaching and learning processes that have been well 
108 | Jurnal Office, Vol.3, No.2, 2017

implemented. So the professional competency of the introductory teacher administration department majoring in office administration at YPLP PGRI 1 Makassar is well implemented.

Keywords: Competence, professionals, office administration

\section{PENDAHULUAN}

Pendidikan dalam konteks upaya membangun suatu peradaban merupakan salah satu kebutuhan (jasa) asasi yang dibutuhkan oleh setiap manusia dan kewajiban yang harus diemban oleh negara agar dapat membentuk masyarakat yang memiliki pemahaman dan kemampuan untuk menjalankan fungsi-fungsi kehidupan yang selaras dengan fitrahnya serta mampu mengembangkan kehidupanya menjadi lebih baik dari setiap masa ke masa berikutnya. Pada dasarnya pendidikan merupakan upaya yang dilakukan manusia untuk memperoleh pengetahuan dan keterampilan. Berdasarkan ulasan tersebut dapat diartikan bahwa pendidikan adalah upaya peningkatan kualitas sumber daya manusia (Fransiska, 2016). Oleh karena itu peran guru sebagai tenaga pendidik yang menyampaikan materi kepada peserta didiknya merupakan ujung tombak dalam pembangunan pendidikan nasional terutama dalam pendidikan formal.

Hampir semua orang harus mengenyam pendidikan, sebab pendidikan tidak pernah terpisah dari kehidupan manusia, anak-anak menerima pendidikan dari orang tuanya dan manakala anak-anak sudah dewasa dan berkeluarga mereka juga akan mendidik anak. Begitu pula di sekolah dan perguruan tinggi, para siswa dididik oleh guru dan dosen. Pendidikan berfungsi membantu peserta didik dalam pengembangan dirinya, pengembangan semua potensi, kecakapan serta

karakteristik pribadinya ke arah yang positif. Pendidikan berfungsi mengembangkan apa yang secara potensial dan aktual telah dimiliki peserta didik, sebab peserta didik bukanlah gelas yang kosong yang harus diisi dari luar. Dunia pendidikan dewasa ini berkembang semakin pesat dan semakin kompleksnya persoalan pendidikan yang dihadapi bukanlah tantangan yang dibiarkan begitu saja, tetapi memerlukan pemikiran yang konstruktif demi tercapainya kualitas yang baik. Persoalan yang dimaksud diantaranya adalah kompetensi mengajar guru. Karena guru sebagai tenaga pendidik yang paling banyak berhubungan dengan peserta didik diharuskan mempunyai kompetensi yang baik dalam pelaksanaan kegiatan pembelajaran. Karena Guru sebagai orang yang berwenang dan bertanggung jawab terhadap pendidikan siswa, baik secara individual maupun secara klasikal baik di sekolah maupun diluar sekolah minimal harus memiliki dasar-dasar kompetensi sebagai wewenang dalam menjalankan tugasnya.

Seorang guru perlu memiliki kepribadian, menguasai bahan pelajaran dan menguasai cara-cara mengajar sebagai kompetensinya. Tanpa hal tersebut guru akan gagal dalam melaksanakan tugasnya. Jadi kompetensi mengajar harus dimilki oleh seorang guru yang merupakan keterampilan dalam mengelola kegiatan pendidikan. Dengan demikian guru mempunyai kompetensi mengajar mampu menciptakan lingkungan balajar yang efektif dan menyenangkan serta lebih mampu mengelola 
kelasnya sehingga hasil belajar siswa berada pada tingkat yang optimal. Disamping hal tersebut di atas, "Kompetensi dalam dalam proses interaksi belajar mengajar dapat pula menjadi alat motivasi ekstrinsik, guna memberikan dorongan dari luar diri siswa".

Undang-Undang No.20 Tahun 2003 tentang Sistem Pendidikan Nasional mengatakan bahwa:Pendidikan adalah usaha sadar dan terencana untuk mewujudkan suasana belajar dan proses pembelajaran agar peserta didik secara aktif mengembangkan potensi dirinya untuk memiliki kekuatan spiritual keagamaan, pengendalian diri, kepribadian, kecerdasan, akhlak mulia, serta keterampilan yang diperlukan dirinya, masyarakat, bangsa, dan negara.

Wina Sanjaya mengatakan :

Seorang guru harus meyakini bahwa pekerjaannya merupakan pekerjaan profesional yang merupakan upaya pertama yang harus dilakukan dalam rangka pencapaian standar proses pendidikan sesuai dengan harapan.

Uandang-Undang Negara Republik Indonesia Nomor 14 Tahun 2005 Pasal 1 tentang Guru dan Dosen dijelaskan bahwa :

"Guru adalah pendidik profesional dengan tugas utama mendidik, mengajar, membimbing, mengarahkan, melatih, menilai, dan mengeveluasi peserta didik pada pendidikan anak usia dini jalur pendidikan formal, pendidikan dasar, dan pendidikan menengah".

Sehubungan dengan penjelasan di atas maka dapat disimpulkan bahwa seorang guru harus memiliki kompetensi sebagaimana yang dimaksud dalam Undang-Undang No.14 Tahun 2005 pasal 8 meliputi kompetensi pedagogik, kompetensi kepribadian, kompetensi sosial dan kompetensi profesional melalui pendidikan profesi.

Guru sebagai pendidik yang profesional pada suatu sekolah memilki peran yang sangat penting mulai dari peningkatan prestasi belajar pesrta didik sampai pada penentu keberhasilan peserta didiknya. Guru menentukan keberhasilan peserta didik (Davis, 2003; Dobber, Zwart, Tanis, \& van Oers, 2017; Taylor, Yates, Meyer, \& Kinsella, 2011). Guru profesional adalah kemampuan seorang guru untuk melaksanakan tugas pokoknya sebagai seorang pendidik dan pengajar yang meliputi kemampuan dalam merencanakan, menjalankan, dan mengevaluasi hasil pembelajaran. Pendidikan berintikan antara pendidik (guru) dan pesertan didik (siswa) untuk mencapai tujuan tujuan pendidikan. Dalam situasi tertentu tugas guru dapat diwakilkan atau dibantu oleh unsur lain seperti media teknologi, tetapi tidak dapat digantikan. Mendidik adalah pekerjaan profesional, oleh karena itu, guru sebagai pelaku utama pendidikan merupakan pendidik profesional. Sebagai pendidik profesional guru bukan saja dituntut melaksanakan tugasnya secara profesional, tetapi juga harus memiliki pengetahuan dan 
110 | Jurnal Office, Vol.3, No.2, 2017

kemampuan profesional (Liston, Borko, \& Whitcomb, 2008; Lunenberg \& Willemse, 2006; McCormack, Gore, \& Thomas, 2006).

Proses pembelajaran dapat terlaksana dengan baik jika didukung oleh kompetensi yang dimilki oleh guru, karena peranan dan kemampuan guru dalam menciptakan lingkungan yang efektif akan berpengaruh besar dalam meningkatkan prestasi belajar siswa. Dengan adanya kompetensi-kompetensi guru yang dimilki oleh seorang guru sebagai keterampilannya untuk menjadi guru profesional dalam meningkatkan prestasi belajar siswa, apalagi peserta didik memilki karakter-karakter belajar yang berbedabeda.

Peran guru dalam hal pendidikan, tidak dapat mungkin digantikan oleh perangkat lain, sebab siswa adalah organisme yang sedang berkembang dengan memerlukan bimbingan seorang guru. Peran guru dalam proses pembelajaran bukan hanya sebagai model atau teladan bagi siswa yang diajarnya tetapi juga sebagai pengelola pembelajaran. Peran guru yang sangat menentukan terlaksanannya proses pembelajaran dengan baik di sekolah digambarkan oleh Kunandar bahwa salah satu faktor utama yang menentukan mutu pendidikan adalah guru.

Gurulah yang berada digarda terdepan dalam menciptakan sumber daya manusia. Guru berhadapan langsung dengan para peserta didik dikelas melalui proses belajar mengajar. Di tangan gurulah akan lahir peserta didik yang berkualitas, baik secara akademis, skill (keahlian), kematangan emosional, dan moral serta spiritual. Dengan demikian, akan dihasilkan generasi masa depan yang siap hidup dengan taman zamannya. Oleh karena itu, diperlukan sosok guru yang mempunyai kualifikasi, kompetensi, dan dedikasi yang tinggi dalam menjalankan tugas profesionalnya.

Guru profesional adalah kemampuan seorang guru untuk melaksanakan tugas pokoknya sebagai seorang pendidik dan pengajar yang meliputi kemampuan dalam merencanakan, menjalankan, dan mengevaluasi hasil pembelajaran. Pendidikan berintikan antara pendidik (guru) dan peserta didik (siswa) untuk mencapai tujuantujuan pendidikan. Dalam situasi tertentu tugas guru dapat diwakilkan atau dibantu oleh unsur lain seperti media teknologi, tetapi tidak dapat digantikan. Mendidik adalah pekerjaan profesional, oleh karena itu, guru sebagai pelaku utama pendidikan merupakan pendidik profesional. Sebagai pendidik profesional guru bukan saja dituntut melaksanakan tugasnya secara profesional tetapi juga harus memiliki pengetahuan dan kemampuan profesional.

Guru secara langsung berusaha mempengaruhi, membina dan mengembangkan kemampuan siswa agar menjadi manusia cerdas, terampil dan bermoral tinggi. Di tangan gurulah masa depan bangsa diletakan, maka guru menjadikan masyarakat menjadi pandai, mencetak tenaga-tenaga ahli, dan mencetak pemimpin-pemimpin negara. Dengan demikian guru bertanggung jawab mempersiapkan generasi guna mensukseskan pembangunan bangsa. Meskipun tugas dan tanggung jawab guru tidak terbatas di sekolah, tetapi yang memberikan corak yang khas sebagai suatu profesi adlah 
Fadly Fadlun Renrohan, Sirajuddin Saleh, Muhammad DarwisAnalisis Kompetensi .... |111

peranannya di sekolah, terutama tugas dan tanggung jawabnya dalam mengajar. Oleh karena itu kemampuan profesional guru dalam mengajar haruslah mendapat perhatian yang sungguh-sungguh. Seorang guru harus selalu berusaha meningkatkan kemampuan profesionalnya dan secara terpadu menerapkan dalam pengajarannya, terutama keprofesionalannya dalam menyampaikan materi pelajaran dengan metode yang sesuai dengan kemampuan siswa, sehingga siswa dapat mencapai prestasi belajar yang optimal.

Berdasarkan hasil observasi awal yang dilakukan oleh peneliti khususnya pada mata pelajaran Pengantar Administrasi Perkantoran di SMK YPLP PGRI 1 Makassar pada tanggal 2 April 2018, di mana penulis menemukan masih ada guru yang jarang mengatur tempat duduk di kelas sebelum proses belajar dimulai sehingga peserta didik banyak yang belum siap dalam proses pembelajaran yang mengakibatkan suasana kelas menjadi kurang kondusif, memotivasi siswa untuk melibatkan diri secara aktif dan dalam memberikan kesimpulan. Disamping itu, masih jarangnya pula melakukan proses pembelajaran yang menarik pada setiap pertemuan yang menyebabkan kurang menariknya proses pembelajaran yang berlangsung di kelas, peranan kompetensi profesional guru merupakan hal yang penting untuk menyikapi masalah tersebut.

Berdasarkan uraian latar belakang di atas, maka peneliti tertarik untuk melakukan penelitian dengan mengkaji lebih dalam lagi secara ilmiah dengan judul "Analisis Kompetensi Profesional Guru Pada Mata Pelajaran Pengantar Administrasi di Jurusan Administrasi Perkantoran SMK YPLP PGRI 1 Makassar”.

\section{METODE}

Penelitian ini menggunakan pendekatan kuantitatif dengan jenis penelitian deskriptif yang dirancang untuk mengukur sejauh mana minat mahasiswa untuk menjadi guru (Hamdi \& Bahruddin, 2015). Penelitian ini menggunakan teknik analisis deskriptif dengan menggunakan tabel frekuensi dan persentase. Untuk mengukur variabel digunakan angket berskala Likert yang akan diisi oleh responden sesuai dengan indikator variabel. Adapun populasi dalam penelitian ini adalah mahasiswa Program Studi Pendidikan Administrasi Perkantoran Fakultas Ilmu Sosial Universitas Negeri Makassar yang masih aktif sebanyak 263 mahasiswa, dengan menggunakan teknik Probability Sampling berupa Proportionate Stratified Random Sampling. Dengan menggunakan penarikan sampel sebesar $20 \%$ dari jumlah populasi atau sama dengan 52,6 dibulatkan menjadi 53 mahasiswa mulai dari angkatan 2014, 2015, 2016 dan 2017. Pengumpulan data dalam penelitian ini menggunakan teknik angket, wawancara, dan dokumentasi. Data yang terkumpul akan dianalisis dengan menggunakan tabel frekuensi dan persentase. 
112 | Jurnal Office, Vol.3, No.2, 2017

\section{HASIL PENELITIAN DAN PEMBAHASAN}

Berdasarkan hasil penelitian yang dilakukan peneliti mengenai Analisis kompetensi profesional guru pada mata pelajaran pengantar administrasi jurusan administrasi perkantoran SMK YPLP PGRI 1 Makassar secara umum dapat dikatakan telah berjalan dengan baik. Hal tersebut dapat dilihat dari beberapa penjelasan informan yang tentunya berdasarkan lima indikator kompetensi profesional itu sendiri :

\section{Menguasai Landasan Pendidikan}

Praktek pendidikan diupayakan pendidik dalam rangka memfasilitasi peserta didik agar mampu mewujudkan diri sesuai kodrat dan martabat kemanusiaannya. Semua tindakan pendidik diarahkan kepada tujuan agar peserta didik mampu melaksanakan berbagai peranan sesuai dengan statusnya, dan tentunya berdasarkan nilai-nilai dan norma-norma yang diakui. Dalam pernyataan diatas tersurat dan tersirat bahwa pendidikan berfungsi memanusiakan manusia, bersifat normatif, dan karena itu mesti dapat dipertanggung jawabkan. Sehubungan dengan hal diatas, praktek pendidikan tidak boleh dilaksanakan secara sembarang, sebaliknya harus dilaksanakan secara didasari dan terencana. Artinya, praktek pendidikan harus memiliki suatu landasan yang kokoh, jelas dan tepat tujuannya, tepat isi kurikulumnya, dan efisien serta efektif cara-cara pelaksanaanya.

Penguasaan landasan pendidikan oleh guru mata pelajaran pengantar administrasi dapat dikatakan sudah baik, hal ini dapat kita lihat dari penjelasan berikut ini: Semua tujuan pendidikan itu mutlak sudah seharusnya jelas, jadi jika disisni khususnya menyangkut profesionalnya seorang guru dalam hal ini pada mata pelajaran pengantar administrasi di jurusan pendidikan administrasi perkantoran itu yang pertama dan yang paling utama adalah seorang guru itu harus paling tidak memiliki keterampilan dan pengetahuan mengenai apa yang seharusnya dicapai di administrasi perkantoran itu sendiri, antara lain yang paling menjadi inti yaitu bagaimana melakukan pengelolaan surat yaitu kearsipan, bagaimana menggunakan peralatan atau sarana yang ada ini khususnya untuk komputer dengan menggunakan mengetik sepuluh jari untuk memaksimalkan penggunaanya, dan kemudian penggunaan peralatan lain, itu semua harus maksimal agar apa yang menjadi tujuan di pendidikan administrasi perkantoran itu dapat tercapai, dan kalaupun misalnya tidak memiliki keterampilan mengenai bagaimana menyusun surat, bagaimana mengelola surat dengan baik, surat masuk surat keluar, bagaimana menggunakan peralatan untuk mengetik misalnya (komputer) dan bagaimana menggunakan peralatan yang lain misalnya LCD, bagaimana menggunakan peralatan lain yang berkaitan dengan proses pengajaran. Itu semua tidak harus dengan teori dia milki, tetapi juga harus memiliki ilmunya, dan mampu mempraktekanya. Itulah yang menjadi inti sebenarnya di dalam pencapaian tujuan pendidikan terutama khususnya untuk administrasi perkantoran. Jelas penting sebagai seorang guru harus mengenal dulu apa tujuan pendidikan itu sendiri, karena kalau kita tidak mengenal apa sebenarnya apa tujuan pendidikan kita tidak bisa mengarahkan anak-anak sampai dimana dia harus belajar kemudian apa yang akan dia capai nantinya setelah belajar tiga tahun, sebenarnya penting sekali. 
Fadly Fadlun Renrohan, Sirajuddin Saleh, Muhammad DarwisAnalisis Kompetensi .... $\mid 113$

\section{Menguasai Bahan Pengajaran}

Menguasai bahan pengajaran adalah satu kemampuan dasar yang harus dimiliki oleh guru dalam upaya melaksanakan upaya kompetensi profesional. Setiap guru yang mampu menguasai kompetensi profesional wajib mampu menguasai bahan ajar. Kalau kita tidak menguasai materi yang mau diajarkan itu nantinya tidak terarah kita dalam memberikan pelajaran, jadi memang harus sudah ada perencanaan bahwa ini yang harus disampaikan di pertemuan ini, itu sehingga ada RPP, bahkan ada lagi program perencanaan karena apa yang harus dicapai pada pertemuan itu harus disampaikan bahwa ini yang mau di capai.

Jadi harus sudah ditentukan sebelumnya bahwa ini yang mau didapat pada pertemuan ini misalnya penilaian itu menilai semua tidak mungkin hanya satu kali penilaian, tapi khusus misalnya pada pertemuan ini saya mau menilai ini begitu, yang mau saya dapat pada pertemuan ini jadi harus jelas apa yang mau dicapai sudah kita ketahui didalam memberikan pembelajaran itu, jadi materi memang harus dikuasai tidak boleh tidak, apa yang mau disampaikan kalau materi tidak dikuasai jadi penting penguasaan materi bagi seorang guru yang akan mengadakan pengajaran. Tujuan daripada postes/pengayaan untuk mengetahui apakah peserta didik mengerti dengan materi yang kita sampaikan, jadi penting karena sebagai bahan untuk guru akan mengetahui bahwa ini point yang harus diulang itu tujuan nya sehingga diadakan yang namanya postes, mana yang tidak dimengerti saja yang diulang. Jadi jika misalnya siswa mengerti semua maka tidak perlu diulang, paling beberapa saja tidak seperti misalnya ada yang tidak mengerti betul maka harus dilakukan penekanan kembali.

Tentunya kita harus menguasai kurikulumnya karena sebenarnya kita harus kenal dulu sebelum menguasai, kita harus mengenal dulu kurikulumnya seperti apa kemudian apa yag kita kenal itu dengan proses-proses mengajar kemudian mencaricari informasi bisa seperti itu. Jadi betul pengayaan itu didapatkan setelah adanya hasil atau evaluasi yang dilakukan seperti yang barubaru ini dilakukan setelah melakukan semester ujian penilaian akhir semester kemudian hasil dari kerja siswa itu kemudian diperiksa apakah ada yang belum tercapai kemudian dan ada yang menjawab tapi belum maksimal, yang belum maksimal ini lah yang dilakukan pengayaan dan tidak semua soal-soal yang diberikan itu dilakukan pengayaan artinya misalnya soalnya satu sampai sepuluh kemudian ada satu atau dua nomor itu yang dimana mereka belum maksimal dalam menjawab maka dua nomor itu saja yang dilakukan pengayaan tidak semuanya. Jadi penting sebenarnya karena untuk mengembangkan siswa itu sendiri juga.

\section{Penyusunan Program Pengajaran}

Pengajaran sebagai suatu sistem yang bertujuan, yang harus direncanakan oleh seorang guru berdasarkan pada kurikulum yang berlaku. Penyusunan program belajar mencakup kegiatan merumuskan tujuan pembelajaran, merumuskan isi / materi pelajaran yang harus dipelajari, merumuskan kegiatan belajar dan merumuskan sumber belajar / media pembelajaran yang akan digunakan serta merumuskan evaluasi belajar.

Proses penyusunan program pengajaran sebenarnya kalau kurikulum yang dulu itu sudah dibuatkan yang namanya rencana pelaksanaan pembelajaran (RPP) tapi sekarang untuk kurikulum 13 revisi 2017 ini sebenarnya hanya diberikan KD semata kemudian perangkat pembelajaran yang lain dibuatkan sendiri seperti RPP sesuai dengan KD yang diberikan, karena dulu RPP nya sudah disiapkan tinggal dilaksanakan sekarang dibuat sesuai dengan KD nya 
kemudian dilaksankan karena semua beerpatokan pada KD Karena dalam KD ada pengetahuan dan keterampilan, pengetahuan adalah teorinya keterampilan adalah hasil dari teorinya.

Tentunya harus menguasai kurikulum karena sebenarnya seorang tenaga pengajar harus mengenal dulu sebelum menguasai, maka harus mengenal dulu kurikulumnya seperti apa kemudian apa yang dikenal itu dengan proses-proses mengajar kemudian mencari cari informasi bisa seperti itu. Jadi betul pengayaan itu didapatkan setelah adanya hasil atau evaluasi yang dilakukan. contoh setelah melakukan semester ujian penilaian akhir semester kemudian hasil dari kerja siswa itulah yang kemudian diperiksa apakah ada yang belum tercapai kemudian dan ada yang menjawab namun belum maksimal, yang belum maksimal inilah yang dilakukan pengayaan dan tidak semua soal-soal yang diberikan itu dilakukan pengayaan.

Jadi penting sebenarnya karena untuk mengembangkan siswa itu sendiri juga. Prosesnya sebenarnya kalau kurikulm yang dulu itu sudah dibuatkan yang namanya rencana pelaksanaan pembelajaran (RPP) tapi sekarang untuk kurikulum 13 revisi 2017 ini kita sebenarnya hanya diberikan KD saja kemudian perangkat pembelajaran yang lain kita yang buat sendiri seperti RPP sesuai dengan KD yang diberikan, jadi proses nya sebenarnya susah-susah gampang karena dulu RPP nya sudah disiapkan tinggal dilaksanakan sekarang dibuat sesuai dengan KDnya kemudian dilaksankan karena semua beerpatokan pada KD Karena dalam KD ada pengetahuan dan keterampilan, pengetahuan adalah teorinya keterampilan adalah hasil dari teorinya. Sebenaranya ada dalam bahan ajar atau materinya, sebenarnya materinya itu diambil dari indikator pembelajaranya, indikator pembelajaran diambil dari kompetensi dasarnya itu semua sudah ada dalam RPP satu rangkaian jadi terstruktur ada kompetensi dasar kemudian indikator pembelajaran, tujuan pembelajaran, materi ajarnya, kemudian proses belajar nya.

Kalau strategi sebenarnya ada juga dalam RPP jadi sebelum guru masuk ke dalam kelas sudah harus ditentukan dulu strategi apa yang akan diterapkan nantinya tetapi kadang ditemukan hal yang bebeda di kelas kadang strategi yang sudah ditentukan sebelumnya itu terkadang tidak sesuai dengan apa yang telah ditetapkan sebelumnya karena ada macam-macam masalahnya makanya ada strategi alternatif sebenarnya yang harus ditentukan.

Kemudian kalau media pembelajarannya dilihat dari materi yang akan dibawakan nantinya misalkan materinya berupa hanya penjelasan-penjelasan maka yang digunakan media LCD kolektor, laptop kemudian kalau medianya belajar kelompok diberikan tugas mencari bahanbahan ataukah itu di internet bahkan kita kadang menyarankan untuk mencarinya di hp nya sendiri tentu tidak lepas dari arahan guru jadi hp nya tidak digunakan hanya untuk fb, wa dan lain-lain, tapi dimanfaatkan sesuai dengan apa yang menjadi kebutuhan belajar. Kalau sumber belajar disini tersedia banyak buku tetapi juga pengembangan materi-materi ini dengan sumber belajar pendukung tentunya internet bisa dijadikan sebagai sumber belajar pendukung jadi tidak hanya satu reverensi saja seperti buku, tapi ada juga artikel-artikel yang bisa dimanfaatkan untuk kepentingan belajar mengajar.

\section{Pelaksanaan Program Pengajaran}

Pelaksanaan kagiatan pengajaran dilakukan melalui pembahasan tema yang diambil mulai dari lingkungan terdekat dari sampai dengan yang terjauh. Tema-tema tersebut dijabarkan dalam bentuk sub-sub tema dalam bentuk program kegiatan pembelajaran yang bersifat operasional. Untuk menciptakan kondisi belajar mengajar yang tepat maka sangat penting bagi seorang guru 
Fadly Fadlun Renrohan, Sirajuddin Saleh, Muhammad DarwisAnalisis Kompetensi .... $\mid 115$

untuk selalu memperhatikan 3 hal yaitu, 1). Keprihatinan guru, 2). Kemampuan guru mengelola kedekatan dan kontrol, 3) pengaruh lingkungan sosial dalam masyarakat.

Kalau untuk gaya ruangan belajarnya sebenarnya gaya seperti biasa atau clasiscal tapi misalnya pada pertemuan sebelumnya dengan gaya ruangan sperti itu tidak efektif maka diubah menjadi gaya berbentuk $U$ jadi tidak hanya gaya clasical tapi bebentuk $U$ juga karena sangat penting sebenarnya untuk mengatur ruanganya karena dapat berpengaruh juga pada hasil belajar siswa nantinya, karena kalau gaya clasical itu kadang ada siswa yang di belakang itu cerita-cerita kemudian ada yang kaya ngantuk itu semua sebenarnya harus diperhatikan jangan sampai ada temanya yang serius belajar kemudian ada temanya yang dibelakang hanya main-main saja jadi harus semuanya dilihat.

\section{Menilai hasil dan proses belajar mengajar yang telah dilaksanakan}

Undang-Undang Negara Republik Indonesia Nomor 14 Tahun 2005 Pasal 1 tentang Guru dan Dosen dijelaskan bahwa: Guru adalah pendidik profesional dengan tugas utama mendidik, mengajar, membimbing, mengarahkan, melatih, menilai, dan mengeveluasi peserta didik pada pendidikan anak usia dini jalur pendidikan formal, pendidikan dasar, dan pendidikan menengah".

Penilaian adalah proses memberikan atau menentukan nilai kepada objek tertentu berdasarkan kriteria tertentu. Untuk dapat menentukan suatu nilai atau harga suatu objek, diperlukan adanya ukuran atau kriteria. Dalam Penilaian Pendidikan, mencakup tiga sasaran utama yakni program pendidikan, proses belajar mengajar dan hasil belajar.

Keberhasilan pengajaran tidak hanya dilihat dari hasil belajar yang dicapai oleh siswa, tetapi juga dari segi prosesnya. Hasil belajar pada dasarnya merupakan akibat dari suatu proses belajar. Ini berarti optimalnya hasil belajar siswa tergantung pula pada proses belajar siswa dan proses mengajar guru. Oleh sebab itu, perlu dilakukan terhadap proses belajar mengajar. Hasil belajar merupakan hal yang dapat dipandang dari dua sisi yaitu sisi siswa dan sisi guru. Dari sisi siswa, hasil belajar merupakan tingkat perkembangan mental yang lebih baik bila dibandingkan pada saat sebelum belajar. Tingkat perkembangan mental tersebut terwujud pada ranah jenisjenis kognitif, afektif, dan psikomotor. Sedangkan dari sisi guru, hasil belajar merupakan saat terselesaikannya bahan pembelajaran.

Dalam tahap penilaian guru mempunyai banyak metode tapi di jurusan administrasi perkantoran SMK YPLP PGRI 1 Makassar ada ulangan harian kemudian ada mid semester, kemudian semester itu sendiri. untuk pengetahuan ada juga keterampilan kalau keterampilan itu adalah tugas, atau yang biasa di kenal dengan kognitif, afektif dan psikomotorik, kemudian ada penilaian sikap misalnya bisa diambil bagaimana sosialnya, bagaimana melaksanakan Ibadah misalnya ada harus dipanggil ada yang tanpa dipanggil sudah pergi sendiri ada juga yang memang lari-lari dan sebagainya itu bisa di nilai untuk sikap jadi ada tiga yaitu 1). sikap afektif 2). pengetahuan kognitif 3 ). Keterampilan psikomotorik, dari kesemua itulah yang nantinya dimasukan ke dalam niali raport. Jadi ada tujuan pembelajaran yang telah ditetapkan jadi apakah tujuan pembelajaran itu sudah tercapai atau belum, nah inilah yang akan kita evaluasi nantinya apakah prestasi muridnya itu sendiri sudah sesuai dengan tujuan pembelajaranya ataukah belum, disamping itu penialaian pengetahuan, keterampilan dan sikap tetap harus dilaksanakan. 
116| Jurnal Office, Vol.3, No.2, 2017

\section{SIMPULAN}

Berdasarkan hasil penelitian dan pembahasan yang telah dilakukan oleh peneliti maka dapat dipahami bahwa kompetensi profesional guru pada jurusan administrasi perkantoran SMK YPLP PGRI 1 Makassar pada umunya sudah terimplementasi dengan baik. Hal ini dinilai dari kelima indikator dalam melaksanak tugas sebagai pengajar profesional, yang pertama tahap penguasaan landasan pendidikan di kelas yang hasilnya dikategorikan baik, kedua tahap penguasaan bahan pengajaran yang dilakukan guru saat di dalam kelas dinilai sudah berjalan dengan baik, yang ketiga langkah penyususunan program pengajaran yang dimana hasilnya juga dinilai berjalan dengan baik, yang keempat yaitu tahap melaksanakan program pengajaran yang dimana juga dapat dikatakan sudah berjalan dengan baik, dan yang kelima yaitu tahap penilaian hasil dan proses belajar mengajar yang telah dilaksanakan juga sudah dapat dikategorikan baik. Pemilihan kompetensi profesional guru pada mata pelajaran pengantar administrasi pada jurusan administrasi perkantoran di SMK YPLP PGRI 1 Makassar juga dikarenakan mata pelajaaran tersebut harus disampaikan secara jelas secara langsung dari guru bersangkutan dan juga mata pelajaran pengantar administrasi ini tentunya membutuhkan penjelasan yang lebih detail agar para siswa dapat mempratekkannya dengan baik.

\section{DAFTAR PUSTAKA}

Davis, H. A. (2003). Conceptualizing the Role and Influence of Student-Teacher Relationships on Children's Social and Cognitive Development. Educational Psychologist. https://doi.org/10.1207/S15326985EP3804_2

Dobber, M., Zwart, R., Tanis, M., \& van Oers, B. (2017). Literature review: The role of the teacher in inquiry-based education. Educational Research Review. https://doi.org/10.1016/j.edurev.2017.09.002

Fransiska, C. (2016). Pengaruh kompetensi profesional guru terhadap kualitas proses pembelajaran pada paket keahlian administrasi perkantoran di smk negeri 1 bungoro kabupaten pangkep. Jurnal Office, 2(2), 163-172.

Hamdi, A. S., \& Bahruddin, E. (2015). Metode penelitian kuantitatif aplikasi dalam pendidikan. Bogor: Deepublish.

Liston, D., Borko, H., \& Whitcomb, J. (2008). The Teacher Educator's Role in Enhancing Teacher Quality. Journal of Teacher Education. https://doi.org/10.1177/0022487108315581

Lunenberg, M., \& Willemse, M. (2006). Research and professional development of teacher educators. European Journal of Teacher Education. https://doi.org/10.1080/02619760500478621

McCormack, A., Gore, J., \& Thomas, K. (2006). Early career teacher profesional learning. AsiaPacific Journal of Teacher Education. https://doi.org/10.1080/13598660500480282

Taylor, M., Yates, A., Meyer, L. H., \& Kinsella, P. (2011). Teacher professional leadership in support of teacher professional development. Teaching and Teacher Education. https://doi.org/10.1016/j.tate.2010.07.005 